\title{
Analisis Penanda Tunggal Karakter Agronomi dengan Marka Mikrosatelit pada Tanaman Padi (Oryza sativa L.)
}

\section{Single Marker Analysis of Agronomic Traits with Microsatellites Marker in Rice (Oryza sativa L.)}

\author{
Idayatul Hanifa, Rani Agustina Wulandari', Muhammad Habib Widyawan \\ ${ }^{1}$ Departemen Budidaya Pertanian, Fakultas Pertanian, Universitas Gadjah Mada \\ Jalan Flora No. 1, Bulaksumur, Sleman, Yogyakarta 55281, Indonesia. \\ $\left.{ }^{*}\right)$ Penulis untuk korespodensi E-mail: rani.akyun@gmail.com
}

Diajukan: 30 Desember 2020/Diterima: 30 September 2021 /Dipublikasi: 26 November 2021

\begin{abstract}
Indonesia has diverse accessions of local rice, which are useful as genetic diversity resources in order to create a superior rice cultivar. Molecular markers are needed as an alternative to detect the locus which control agronomic traits in rice. Microsatellites or simple sequence repeats is one of molecular markers that is widely used to analyze diversity and to locate genes and quantitative trait loci (QTL) on rice chromosomes. This study aimed to identify association between microsatellite marker and agronomic traits of 45 local rice accessions collected by Department of AgronomyUniversitas Gadjah Mada through Single Marker Analysis; to identify the effect of major gene and minor gene in every observed agronomic trait in this study. Detection of microsatellite allele polymorphism was carried out by visualization of PCR amplicons by electrophoresis on metaphor gel. The result of genotype diversity was analyzed by using Rstudio and Single Marker Analysis. Regression analysis identified association between genotypes and agronomic characters in rice local accessions. The result from this study was every single locus in 8 markers in this study associated with 13 different agronomic characters and every locus which associated with these agronomic characters controlled by major genes due to high determination value of more than $10 \%$ $\left(R^{2}>10 \%\right)$.
\end{abstract}

Keyword: genetic diversity; local rice accessions; quantitative trait loci (QTL); SSR marker; traits association

\section{INTISARI}

Indonesia memiliki beragam aksesi padi lokal yang bisa menjadi sumber keragaman genetik dan bisa digunakan untuk merakit suatu kultivar padi unggul. Untuk itu, diperlukan marka molekuler sebagai suatu alternatif untuk mendeteksi lokus-lokus yang mengatur karakter agronomi pada tanaman padi. Mikrosatelit atau simple sequence repeat (SSR) merupakan salah satu marka molekuler yang telah banyak digunakan untuk analisis keragaman dan penentuan lokasi gen dan lokus sifat kuantitatif (QTLS) pada kromosom tanaman padi. Penelitian ini bertujuan untuk mengidentifikasi keterpautan marka mikrosatelit dengan karakter agronomi dari $\mathbf{4 5}$ aksesi padi lokal koleksi Departemen Budidaya Pertanian UGM melalui Analisis Penanda Tunggal dan juga untuk mengetahui pengaruh gen mayor maupun gen minor pada setiap karakter agronomi yang diamati. Deteksi polimorfisme alel SSR dilakukan dengan visualisasi amplikon hasil polymerase chain reaction (PCR) pada elektroforesis gel metaphore. Data hasil pengamatan genotipe diolah dengan Rstudio untuk 
selanjutnya dilakukan Analisis Marka Tunggal. Dilakukan analisis regresi untuk mengetahui keterpautan genotipe dengan karakter agronomi pada aksesi padi lokal. Hasil yang didapatkan dari penelitian ini adalah setiap lokus pada 8 marka yang digunakan memiliki asosiasi dengan 13 karakter agronomi yang berbeda dan setiap lokus yang berasosiasi dengan karakter agronomi tersebut diatur oleh gen mayor karena nilai determinansi yang melebihi $10 \%\left(R^{2}>10 \%\right)$.

Kata kunci: aksesi padi lokal; asosiasi sifat; keragaman genetik; penanda SSR; quantitative trait loci (QTL)

\section{PENDAHULUAN}

Padi merupakan salah satu tanaman pangan penting dan dikonsumsi oleh lebih dari 3,5 milyar penduduk di dunia untuk pemenuhan kalori $50 \%$ hingga $80 \%$ dengan konsumsi terbesar berada di Asia. Rata-rata produksi padi di Indonesia tahun 2015 adalah 5,3 ton/ha, sedangkan konsumsi rata-rata beras masyarakat Indonesia per kapita per minggu mencapai 1,626 kg (BPS, 2015a). Laju pertumbuhan penduduk Indonesia dari 2010-2014 mencapai 1,4\% per tahun dan diproyeksikan jumlah penduduk dari tahun 2015 yang sekitar 255 juta mencapai 296 juta pada tahun 2025 (BPS, 2015b). Hingga saat ini persediaan beras di Indonesia belum bisa memenuhi permintaan beras yang terus meningkat seiring peningkatan jumlah penduduk. Peningkatan produksi padi perlu didukung program pemuliaan di dalam perakitan varietas padi unggul, kegiatan tersebut membutuhkan keragaman genetik padi sebagai breeding material.

Padi lokal merupakan salah satu plasma nutfah yang berpotensi sebagai sumber genetik yang dapat dimanfaatkan dalam program pemuliaan tanaman padi untuk merakit suatu varietas unggul (Mafaza et al., 2018). Informasi dan pengetahuan mengenai keragaman genetik dan hubungan kekerabatan antar individu sangat penting bagi para pemulia tanaman. Hal ini karena program pemuliaan bergantung pada keragaman genetik yang tinggi yang dapat digunakan dalam membuat rekombinasi untuk merakit suatu varietas baru. Analisis keragaman genetik dengan menggunakan marka molekuler sangat membantu dalam mengelompokkan plasma nutfah. Selain itu penggunaan marka molekuler dimanfaatkan untuk mengetahui lokus-lokus yang mengatur karakter kuantitatif pada tanaman. Marka molekuler yang terpaut dengan beberapa gen (lokus-lokus sifat kuantitatif) dapat membantu mengurangi ukuran populasi dan waktu seleksi dalam program pemuliaan. Selain itu, marka molekuler mampu menyeleksi sifatsifat yang diinginkan pada tahap pembibitan, bahkan untuk sifat yang sangat sulit untuk diamati secara fenotipik dan memerlukan waktu yang lama, seperti morfologi perakaran, resistensi terhadap hama dan penyakit, serta toleransi terhadap cekaman abiotik seperti kekeringan, garam, defisiensi atau keracunan mineral (Prasetiyono et al., 2003).

Saat ini penanda molekuler yang paling umum digunakan untuk mendeteksi keragaman genetik adalah mikrosatelit (Simple Sequence Repeat), karena sifatnya 
yang reproducible, kodominan, dan dapat mendeteksi variasi alel yang tinggi. Penggunaan marka mikrosatelit relatif mudah karena menggunakan teknik polymerase chain reaction (PCR) sehingga dapat menjangkau seluruh kromosom. Oleh karena itu, peluang untuk mendapatkan marka yang terpaut dengan suatu karakter yang penting semakin besar. Pemanfaatan peta keterpautan mikrosatelit dalam perakitan varietas baru juga dapat menghemat waktu, tenaga, dan dana (Prasetiyono et al., 2003). Penelitian ini bertujuan untuk mengetahui keterpautan marka mikrosatelit dengan karakter agronomi melalui Analisis Penanda Tunggal dan untuk mengetahui pengaruh gen mayor maupun gen minor pada setiap karakter agronomi yang diamati.

\section{BAHAN DAN METODE}

\section{Waktu dan tempat penelitian}

Penelitian ini dilaksanakan $\mathrm{d} i$ Laboratorium Genetika dan Pemuliaan Tanaman dan Rumah Kawat, Jurusan Budidaya Pertanian, Fakultas Pertanian, UGM pada bulan September hingga Desember 2019.

\section{Bahan tanaman dan Marka yang digunakan}

Sebanyak 45 aksesi padi dianalisis dengan 9 marka SSR. Aksesi-aksesi tersebut terdiri dari 41 aksesi padi lokal dan 4 varietas padi komersial. Terdapat 9 marka mikrosatelit yang digunakan pada penelitian ini yaitu: RM20A, RM72, RM228, RM518, RM6909, RM7424, RM24393, RM27933, dan DRO.
Selain itu digunakan data dari 13 karakter agronomi dari aksesi padi lokal yang digunakan pada penelitian ini yaitu : tinggi tanaman, umur berbunga, umur panen, jumlah anakan, panjang malai, diameter ruas bawah, jumlah malai pertanaman, lebar daun, panjang daun, lebar daun bendera, panjang daun bendera, panjang bulu, dan bobot 100 gabah.

\section{Isolasi dan Amplifikasi DNA}

DNA diisolasi dari daun-daun muda tanaman padi yang berusia 2 MST. Isolasi DNA dilakukan menurut metode Doyle \& Doyle (1990) yang dimodifikasi. Modifikasi yang dilakukan adalah menaikkan konsentrasi Polyvinylpyrrolidone (PVP) menjadi $2 \%$ dan juga dengan penambahan sodium asetat $3 \mathrm{M}$. DNA diisolasi menggunakan buffer ekstraksi Cetyl Trimethyl Ammonium Bromide (CTAB).

Amplifikasi PCR dilakukan dalam volume 13 $\mu \mathrm{l}$ dengan konsentrasi DNA $30 \mathrm{ng} / \mu \mathrm{l}$ sebanyak $1 \mu \mathrm{l}$, ditambahkan PCR mix Go Taq Green $6.3 \mu \mathrm{l}$, dan primer Forward dan reverse (10 mM) masing-masing $1 \mu \mathrm{l}$. Program PCR yang digunakan sebagai berikut: denaturasi awal pada suhu $95^{\circ} \mathrm{C}$ selama 5 menit, dilanjutkan 36 siklus yang terdiri atas denaturasi pada suhu $95^{\circ} \mathrm{C}$ selama 1 menit, penempelan primer pada suhu $55^{\circ} \mathrm{C}$ selama 1 menit dan suhu $72^{\circ} \mathrm{C}$ selama 1 menit 30 detik, kemudian diikuti dengan pemanjangan primer akhir pada suhu $72^{\circ} \mathrm{C}$ selama 7 menit. Adapun penanda SSR yang digunakan dalam penelitian ini disajikan pada Tabel 1. 
Tabel 1. Daftar Plasma Nutfah yang digunakan dalam Penelitian

\begin{tabular}{|c|c|c|c|c|c|c|c|}
\hline No & Aksesi & Kode & Asal & No & Aksesi & Kode & Asal \\
\hline 1 & 'Ciherang' & CHR & Indonesia & 24 & 99 & BP-116 & Bantul (SPY) \\
\hline 2 & 'Bluebonnet' & BB & United States & 25 & Batang Rimbang & BP-118 & Magelang (CJ) \\
\hline 3 & FR13A & FR13A & India & 26 & Janur & BP-120 & Bantul (SPY) \\
\hline 4 & 'Kasalath' & KAS & Bangladesh & 27 & Minang & BP-126 & Padang (WS) \\
\hline 5 & Rokan & BP-1 & Indonesia & 28 & Merah & BP-133 & Bantul (SPY) \\
\hline 6 & Widas Sawah 1 & BP-9 & Indonesia & 29 & Lokal Merah & BP-134 & Indonesia \\
\hline 7 & Widas Sawah 2 & BP-10 & Indonesia & 30 & Cempo Lombok & BP-135 & Bantul (SPY) \\
\hline 8 & Dewi Sri & BP-117 & Indonesia & 31 & Rojolele Gepyok & BP-137 & Bantul (SPY) \\
\hline 9 & Rojolele & BP-124 & Klaten (CJ) & 32 & Andel Abang & BP-144 & Magelang (CJ) \\
\hline 10 & Slegreng 3 & BP-127 & Indonesia & 33 & Saodah & BP-150 & Magelang (CJ) \\
\hline 11 & Pandan Wangi & BP-130 & Cianjur (WJ) & 34 & Sedani Cendek & BP-152 & Sleman (SPY) \\
\hline 12 & Cempo Merah & BP-131 & SPY & 35 & Melik Ireng & BP-158 & Sleman (SPY) \\
\hline 13 & Mentik Wangi & BP-132 & $\begin{array}{l}\text { Magelang } \\
\text { (CJ) }\end{array}$ & 36 & Raket Putih & BP-166 & Mataram (WNT) \\
\hline 14 & Anak Daro & BP-161 & Solok (WS) & 37 & Padi Beton & BP-167 & Mataram (WNT) \\
\hline 15 & Batang Gadis & BP-218 & Indonesia & 38 & Reket Dodoh & BP-170 & Mataram (WNT) \\
\hline 16 & Mayangan & BP-260 & Indonesia & 39 & Padi Lobak & BP-173 & Mataram (WNT) \\
\hline 17 & Danau Gaung & BP-304 & Indonesia & 40 & Hitam Temen & BP-180 & Wonosobo (CJ) \\
\hline 18 & Gogo Rencah & BP-7 & Indonesia & 41 & Ireng Bulu & BP-181 & Wonosobo (CJ) \\
\hline 19 & $\mathrm{H} 3$ & BP-12 & Indonesia & 42 & Rening & BP-187 & Indonesia \\
\hline 20 & Merah Panjang & BP-94 & $\begin{array}{l}\text { Magelang } \\
\text { (CJ) }\end{array}$ & 43 & Lembayung Gogo & BP-220 & Indonesia \\
\hline 21 & Gadung Mlathi & BP-56 & Indonesia & 44 & Putho & BP-235 & Indonesia \\
\hline 22 & Ketan Salome 1 & BP-114 & Pandak (SPY) & 45 & Cempo Bulu & BP-237 & Indonesia \\
\hline 23 & Ketan Salome 2 & BP-115 & Bantul (SPY) & & & & \\
\hline
\end{tabular}

Keterangan: keterangan pada bagian kolom asal mengindikasikan provinsi asal aksesi.

CJ: Provinsi Jawa Tengah , WJ: Jawa Timur, SPY: Provinsi Istimewa Yogyakarta, WS : Sumatra Barat, WNT: Nusa Tenggarat Barat 
Tabel 2. Marka Molekuler yang digunakan dalam Penelitian

\begin{tabular}{|c|c|c|c|c|c|c|}
\hline No & Primer & Kromosom & $\begin{array}{l}\text { Annealing } \\
\text { Temperature } \\
\quad\left({ }^{\circ} \mathrm{C}\right)\end{array}$ & Sekuen Primer & Sifat terpaut & Referensi \\
\hline 1 & RM20A & 12 & $55^{\circ} \mathrm{C}$ & $\begin{array}{l}\mathrm{F}: \text { ATCTTGTCCCTGCAGGTCAT } \\
\mathrm{R}: \text { GAAACAGAGGCACATTTCATTG }\end{array}$ & Penggulungan Daun & $\begin{array}{l}\text { Lin et al. } \\
(2007)\end{array}$ \\
\hline 2 & RM72 & 8 & $55^{\circ} \mathrm{C}$ & $\begin{array}{l}\mathrm{F}: \text { :CCGGCGATAAAACAATGAG } \\
\mathrm{R}: \text { GCATCGGTCCTAACTAAGGG }\end{array}$ & Penggulungan Daun & $\begin{array}{l}\text { Lin et al. } \\
(2007)\end{array}$ \\
\hline 3 & RM228 & 10 & $54.2^{\circ} \mathrm{C}$ & $\begin{array}{l}\text { F : CTGGCCATTAGTCCTTGG } \\
\text { R : GCTTGCGGCTCTGCTTAC }\end{array}$ & Penggulungan Daun & $\begin{array}{l}\text { Lin et al. } \\
(2007)\end{array}$ \\
\hline 4 & RM518 & 4 & $55^{\circ} \mathrm{C}$ & $\begin{array}{l}\mathrm{F}: \text { : CTCTTCACTCACTCACCATGG } \\
\mathrm{R}: \text { ATCCATCTGGAGCAAGCAAC }\end{array}$ & Penggulungan Daun & $\begin{array}{l}\text { Lin et al., } \\
\quad(2007)\end{array}$ \\
\hline 5 & RM6909 & 4 & $58.8^{\circ} \mathrm{C}$ & $\begin{array}{l}\text { F : AAGTACTCTCCCGTTTCAAA } \\
\text { R : CCTCCCATAAAAATCTTGTC }\end{array}$ & $\begin{array}{l}\text { Potensi hasil dan } \\
\text { sifat perakaran pada } \\
\text { daerah tadah hujan }\end{array}$ & $\begin{array}{l}\text { Vasant } \\
(2012)\end{array}$ \\
\hline 6 & RM7424 & 9 & $55^{\circ} \mathrm{C}$ & $\begin{array}{l}\text { F : CAGATCAAGCTAGCCACACAGC } \\
\text { R : GAAGGCAGAGCAGGAGAGAAGC }\end{array}$ & Perakaran dalam & $\begin{array}{l}\text { Nogoy et al. } \\
\quad(2016)\end{array}$ \\
\hline 7 & RM24393 & 9 & $56.9^{\circ} \mathrm{C}$ & $\begin{array}{l}\text { F : TAGCTGCTTAGCTTTGACTTGG } \\
\text { R : ATGTAATCCTACGAGGAGATCG }\end{array}$ & Perakaran dalam & $\begin{array}{l}\text { Nogoy et al. } \\
\quad(2016)\end{array}$ \\
\hline 8 & RM27933 & 12 & $54.2^{\circ} \mathrm{C}$ & $\begin{array}{l}\text { F : TCCTCTGTCATATGGCTGTAAACG } \\
\text { R : GGACAAGGAGGAACTATTGATTGG }\end{array}$ & $\begin{array}{l}\text { Potensi hasil ketika } \\
\text { stress air }\end{array}$ & $\begin{array}{l}\text { Boopathi et } \\
\text { al. }(2012)\end{array}$ \\
\hline 9 & DRO & 9 & $60^{\circ} \mathrm{C}$ & $\begin{array}{l}\text { F : GTCCACGAGAGAGAGCATGG } \\
\text { R : ACGAACGCGAATTATTTCTG }\end{array}$ & Perakaran dalam & $\begin{array}{l}\text { Pandit et al. } \\
\quad(2020)\end{array}$ \\
\hline
\end{tabular}

Keterangan : $\mathrm{F}=$ Forward, $\mathrm{R}=$ Reverse 
Analisis Penanda/Marka Tunggal

Analisis marka tunggal dilakukan dengan membagi populasi ke dalam kelaskelas berdasar pada genotipe untuk setiap lokus/marka, dan menganggap adanya sebuah QTL jika terdapat perbedaan nyata dalam ratarata skor fenotipe untuk masing-masing kelompok. Analisis marka tunggal dilakukan dengan analisis regresi. Marka akan dianggap terpaut dengan QTL apabila memiliki nilai peluang kurang dari 0,05 (berbeda nyata pada taraf $5 \%$ ). Analisis regresi dilakukan dengan menggunakan software Rstudio.

\section{HASIL DAN PEMBAHASAN}

Karakter tanaman dibagi menjadi karakter kualitatif dan kuantitatif. Karakter kualitatif adalah sebaran fenotipenya diskontinu yang dikendalikan oleh gen monogenik atau poligenik. Sedangkan karakter kuantitatif adalah sebaran fenotipenya kontinu atau menunjukan sebaran data normal yang dikendalikan oleh banyak gen yang masingmasing gen berpengaruh kecil terhadap ekspresi suatu karakter atau jika sebaran data tidak normal maka efek masing-masing gen berpengaruh besar (gen mayor) (Yohana et al., 2018). Karakter agronomi biasanya dikendalikan oleh beberapa gen pada lokus yang berbeda dimana efek masing-masing gen kecil atau gen minor (Yohana et al., 2018). Gen-gen tersebut secara bersama-sama mempunyai pengaruh yang lebih besar dari pengaruh lingkungan.
Sebanyak 9 marka mikrosatelit dan 13 karakter agronomi digunakan pada penelitian ini untuk selanjutnya dilakukan analisis penanda tunggal. Metode ini adalah metode yang umum dipakai dalam analisis keterkaitan antara data fenotipik dan data genotipik dalam identifikasi QTL. Metode penanda tunggal atau bisa juga disebut dengan single-marker analysis ini merupakan metode statistik yang paling sederhana untuk mendeteksi QTL yang berasosiasi dengan satu marka DNA. Pada metode ini, analisis statistik yang digunakan meliputi uji t (T-test), anova, dan regresi linier. Namun, uji regresi lebih sering dipakai pada metode ini karena nilai koefisien determinasi $\left(R^{2}\right)$ dari marka tersebut menunjukkan variasi fenotipik dari QTL yang terpaut dengan marka DNA (Reflinur dan Lestari, 2015).

Metode analisis penanda tunggal ini membagi populasi kedalam kelas-kelas berdasarkan genotip setiap lokus/marka dan menganggap adanya satu QTL jika terdapat perbedaan nyata dalam rataan skor fenotip untuk masing-masing kelompok (Yohana et al., 2018). Analisis ini untuk mengetahui adanya asosiasi lokus pada marka dengan karakter agronomis tanaman padi yang digunakan pada penelitian ini. Marka molekuler yang terpaut dengan gen-gen (lokus-lokus sifat kuantitatif) dapat membantu mengurangi ukuran populasi dan waktu seleksi dalam program pemuliaan.

Keterpautan antara marka dan karakter agronomi diketahui dengan melihat nilai 
determinansi $\left(R^{2}\right)$ dari analisis regresi. Hal tersebut berkaitan dengan adanya pengaruh dari gen mayor dan gen minor. Pembedaan QTL mayor dan minor didasarkan pada besaran konstribusi suatu QTL terhadap nilai fenotipik, yang ditentukan dari nilai koefisien determinant $\left(\mathrm{R}^{2}\right)$ yang diperoleh dari analisis regresi antara marka DNA dan karakter kuantitatif. Apabila nilai $R^{2}>10 \%$ maka QTL digolongkan sebagai QTL yang bersifat mayor, sebaliknya QTL dengan nilai $\mathrm{R}^{2}<10 \%$ dikategorikan sebagai QTL minor. QTL mayor lebih stabil pada setiap lingkungan, sementara QTL minor sangat sensitif terhadap lingkungan, khususnya QTL yang terkait dengan ketahanan terhadap suatu penyakit tanaman (Reflinur dan Lestari, 2015).

Marka dapat menandai region tertentu pada suatu kromosom. Analisis keterpautan menunjukan bahwa suatu marka terpaut dengan fenotipe tertentu. Hal tersebut menunjukkan bahwa region yang berada dekat dengan marka tersebut mengendalikan fenotipe yang diuji (Yohana et al., 2018).

Tabel 3 menunjukkan hasil analisis penanda tunggal melalui analisis regresi. Hasil yang diperoleh menunjukkan bahwa setiap lokus pada marka menunjukkan asosiasi pada karakter agronomi yang berbeda. Pada marka RM20A yang terletak pada kromosom 12, ketiga lokusnya berasosiasi dengan 13 karakter agronomi yang diujikan kecuali lokus yang berukuran $100 \mathrm{bp}$ yang tidak bersosiasi dengan karakter bobot 100 gabah. Penelitian yang dilakukan Lin et al., (2007) menyebutkan bahwa marka RM20A berasosiasi dengan sifat penggulungan daun yang dapat dijadikan sebagai indikator toleran kekeringan. Marka ini sangat efektif untuk digunakan dalam kegiatan seleksi padi toleran kekeringan. Marka RM20A menunjukkan kemampuan dalam amplifikasi dua fragmen DNA dengan ukuran yang berbeda (Freeg et al., 2016). QTL toleran kekeringan pada kromosom 12 yang telah teridentifikasi yaitu qDTY12.1. Menurut Mishra et al. (2013) qDTY12.1 merupakan salah satu QTL yang menunjukkan pengaruh besar dalam peningkatan hasil padi pada cekaman kekeringan. Letak QTL qDTY12.1 dikromosom 12 pada ukuran 10,2 cM dan marka RM20A terletak pada 9,8 cM (Bernier et al., 2007).

Dari hasil analisis penanda tunggal yang dilakukan (Tabel 2) menunjukkan bahwa setiap lokus pada 8 marka yang digunakan memiliki asosiasi dengan karakter agronomi yang berbeda. Nilai determinansi $\left(R^{2}\right)$ yang didapatkan berkisar antara 0,08721 (RM72) sampai 0,5726 (RM20A). Nilai determinansi yang didapatkan pada analisis penanda tunggal melebihi 0.01 (10\%). Sesuai dengan pernyataan Reflinur dan Puji (2015) apabila nilai $R^{2}>10 \%$ maka $Q T L$ digolongkan sebagai QTL yang bersifat mayor. Oleh karena itu, lokus yang berasosiasi dengan setiap karakter agronomi tersebut diatur oleh gen mayor. 
Tabel 3. Analisis Regresi Lokus Per Marka dengan Sifat Kuantitatif Tanaman

\begin{tabular}{|c|c|c|c|c|c|c|c|c|c|c|c|c|c|c|c|}
\hline \multirow{2}{*}{ Marka } & \multirow{2}{*}{$\begin{array}{c}\text { Letak } \\
\text { Kromo } \\
\text { som }\end{array}$} & \multirow{2}{*}{$\begin{array}{l}\text { Loku } \\
\text { s }\end{array}$} & \multicolumn{13}{|c|}{ Karakter Agronomi (RSquare) } \\
\hline & & & TT & UB & UP & JA & PM & DRB & JM & LD & PD & LDB & PDB & PB & B100 \\
\hline \multirow{3}{*}{ RM20A } & \multirow{3}{*}{12} & 100 & 0,4963 & 0,4298 & 0,394 & 0,3945 & 0,5726 & 0,5374 & 0,2097 & 0,3936 & 0,4607 & 0,4411 & 0,5293 & 0,2786 & \\
\hline & & 130 & 0,2769 & 0,2828 & 0,2577 & 0,2584 & 0,3595 & 0,3484 & 0,1794 & 0,2352 & 0,29 & 0,283 & 0,2869 & 0,2154 & 0,1185 \\
\hline & & 200 & 0,2768 & 0,2282 & 0,2068 & 0,3416 & 0,3142 & 0,3053 & 0,2353 & 0,1941 & 0,268 & 0,2946 & 0,2994 & 0,1738 & 0,1344 \\
\hline \multirow{2}{*}{ RM6909 } & \multirow{2}{*}{4} & 90 & & & & & & & & & & & & 0,1138 & 0,1091 \\
\hline & & 130 & 0,1088 & & & & & & & & & & & & \\
\hline \multirow{5}{*}{$\begin{array}{c}\text { RM2439 } \\
3\end{array}$} & \multirow{5}{*}{9} & 180 & 0,4989 & 0,2054 & 0,1729 & 0,42 & 0,2746 & 0,4439 & 0,3308 & 0,3254 & & 0,434 & 0,4203 & 0,1878 & \\
\hline & & 280 & 0,5279 & 0,2537 & 0,2154 & 0,5005 & 0,3601 & 0,5291 & 0,3744 & 0,3999 & & 0,5326 & 0,4657 & 0,1871 & \\
\hline & & 330 & 0,3508 & & 0,09381 & 0,3567 & 0,3601 & 0,2933 & 0,3031 & 0,3444 & & 0,5035 & 0,3669 & & 0,1494 \\
\hline & & 430 & 0,3508 & & 0,09381 & 0,3567 & 0,1547 & 0,2933 & 0,3031 & 0,3444 & & 0,5035 & 0,3669 & & 0,1494 \\
\hline & & 520 & 0,3508 & & 0,09381 & 0,3567 & 0,1547 & 0,2933 & 0,3031 & 0,3444 & & 0,5035 & 0,3669 & & 0,1494 \\
\hline \multirow{4}{*}{$\begin{array}{c}\text { RM2793 } \\
3\end{array}$} & \multirow{4}{*}{9} & 130 & 0,2982 & 0,2014 & 0,209 & & & & & & 0,268 & 0,1677 & & & \\
\hline & & 199 & & & 0,09263 & & & & & & & & & & \\
\hline & & 355 & 0,2525 & 0,1419 & 0,1516 & 0,1303 & 0,1256 & 0,158 & 0,1504 & 0,2168 & 0,2626 & 0,1349 & 0,1656 & & \\
\hline & & 415 & & & & 0,133 & & & 0,1002 & & & 0,09516 & & & \\
\hline \multirow{2}{*}{ RM72 } & \multirow{2}{*}{8} & 140 & & & & 0,09176 & & 0,1845 & 0,1942 & & 0,1061 & 0,1105 & 0,08721 & & 0,1792 \\
\hline & & 180 & & & & 0,2271 & & & 0,1298 & & & 0,2064 & & & \\
\hline RM228 & 10 & 100 & & & & & 0,1604 & & & & & & & & \\
\hline \multirow{2}{*}{ DRO } & \multirow{2}{*}{9} & 380 & & & & & & & & & & & & & 0,118 \\
\hline & & 450 & & & & 0,2105 & & 0,09114 & 0,1298 & 0,1421 & & 0,2702 & 0,1115 & & 0,134 \\
\hline
\end{tabular}


Marka RM6909 adalah marka yang berlokasi pada kromosom 4. Hasil yang didapatkan menunjukkan bahwa marka ini memiliki asosiasi dengan karakter tinggi tanaman pada lokus 130 bp dan juga karakter panjang bulu dan bobot 100 gabah pada lokus 90 bp. Fujita et al. (2012) menyatakan bahwa marka RM6909 bisa digunakan untuk menyeleksi tanaman yang membawa lokus qTSN4 (Total Spikelet Number). qTSN4 merupakan QTL yang mengekspresikan jumlah bulir permalai pada tanaman padi dan keberadaan QTL ini menandai bahwa jumlah bulir permalai tanaman padi yang besar. Hasil visualisasi gel elektroforesis menggunakan marka RM6909 menunjukkan adanya lebih dari satu fragmen pita DNA.

Marka RM24393 yang terletak pada kromosom 9 berasosiasi dengan 12 karakter agronomi yang diujikan. Marka ini tidak memiliki asosiasi dengan karakter panjang daun. Pada karakter umur berbunga dan panjang bulu hanya berasosiasi dengan lokus 180 bp dan 280 bp dan karakter bobot 100 gabah berasoasiasi dengan lokus 330 b0, 430 bp, dan 520 bp. Uga et al. (2011) menyatakan bahwa QTL yang mengatur perakaran dalam dinamakan Dro1 (Deeper Rooting 1) dipetakan pada $1 \mathrm{cM}$ diantara marka RM24393 dan RM7424. Dari penelitian Uga et al. (2011) tersebut bisa disimpulkan bahwa marka RM24393 juga berpotensi dalam mendeteksi adanya perakaran dalam pada tanaman padi.

Marka RM27933 yang juga berlokasi pada kromosom 9, dari hasil analisis marka tunggal menunjukkan 4 lokus pada marka ini berasosiasi pada karakter yang berbeda (Tabel 2). Pada lokus 130 bp menunjukkan asosiasi dengan karakter tinggi tanaman, umur berbunga, umur panen, panjang daun, dan lebar daun bendera. Lokus 199 bp berasosiasi hanya dengan karakter umur panen. Lokus 355 bp yang memiliki asosiasi dengan karakter tinggi tanaman, umur berbunga, umur anen, jumlah anakan, panjang malai, diameter ruas bawah, jumlah malai pertanaman, lebar daun, panjang daun, lebar daun bendera, dan panjang daun bendera. Lokus 415 bp berasosiasi dengan karakter jumlah anakan, jumlah malai, dan lebar daun bendera. Pada studi yang dilakukan oleh Boopathi et al. (2012) menunjukkan bahwa marka RM27933 terletak pada kromosom 12. Marka tersebut mengandung QTL dengan nama qt/12.1. qt/12.1 yang memiliki pengaruh yang besar terhadap komponen hasil dibawah stress kekeringan. Selain itu, qt/12.1, banyak ditemukan pada kebanyakan varietas padi gogo yang dikenal sangan toleran terhadap cekaman kekeringan. QTL tersebut berperan dalam proses penyerapan air pada tanaman padi, sehingga tanaman padi akan memiliki kemampuan penyerapan air yang baik. Hal tersebut yang membuat tanaman padi memiliki ketahanan terhadap cekaman kekeringan. Hasil identifikasi marka RM27933 menurut penelian sebelumnya bahwa marka ini mengandung qt/12.1 yang berasosiasi dengan karakter komponen hasil pada kondisi stress kekeringan. qt/12.1 
secara konsisten ditemukan pada marka RM27933 pada studi-sudi lain yang dilakukan pada tanaman padi. Marka RM27933 ditemukan dari 10426617 pb sampai 13777049 pb pada kromosom 12 yang didalamnya terdapat 126 jenis protein yang diduga sebagai coding genes.

Marka RM72 yang berada pada kromosom 8, menurut hasil analisis marka tunggal menunjukkan bahwa 2 lokus pada marka ini berasosiasi dengan karakter agronomi yang berbeda. Pada lokus $140 \mathrm{bp}$ memiliki asosiasi dengan karakter jumlah anakan, diameter ruas bawah, jumlah malai, panjang daun, lebar daun bendera, panjang daun bendera, dan bobot 100 gabah. Pada lokus 180 bp hanya berasosiasi dengan karakter jumlah anakan, jumlah malai, dan lebar daun bendera. Pada penelitian yang dilakukan Lin et al. (2012) RM72 terletak pada kromosom 8 dan memiliki QTL Ir8.1 (Leaf Rolling 8.1). QTL ini berperan pada sifat penggulungan daun dan kandungan air relatif. Selain itu, QTL yang berasosiasi dengan tekanan osmotik yang merupakan salah satu mekanisme utama pada toleransi kekeringan, juga berlokasi pada kromosom ini. Berdasarkan studi yang dilakukan oleh Rahman et al. (2015) menyatakan bahwa marka RM72 terpaut dengan 3 karakter agronomis yaitu bobot 1000 gabah, efisiensi penggunaan nitrogen, dan rasio produksi $\mathrm{N}$.

Hasil analisis marka tunggal menunjukkan bahwa marka RM228 yang terletak pada kromosom 10 berasosiasi dengan karakter panjang malai. Menurut penelitian Swamy et al. (2013) marka RM228 mengandung QTL $\quad$ qDTY10.1 yang mempunyai varian aditif dan varian fenotip yang tinggi pada cekaman kekeringan. Letak qDTY10.1 pada ukuran 54,3 cM dan letak marka RM228 pada ukuran 130,3 cM (Solis et al., 2018). Pada penelitian yang dilakukan oleh Talukdar et al. (2017) membuktikan bahwa marka RM228 ini berasosiasi dengan sifat panjang malai.

Marka DRO terletak pada kromosom 9. Hasil analisis marka tunggal menunjukkan lokus 380 bp pada marka ini berasosiasi dengan karakter bobot 100 gabah, sedangkan lokus 450 bp berasosiasi dengan karakter jumlah anakan, diameter ruas bawah, jumlah malai, luas daun, lebar daun bendera, panjang daun bendera, dan bobot 100 gabah. Berdasarkan penelitian yang dilakukan oleh Uga et al. (2011), menunjukkan bahwa terdapat 1 QTL yang mengatur sifat perakaran dalam tanaman padi, yaitu Dro1. Lokus Dro1 ini berada pada kromosom 9. Gen Dro1 merupakan gen yang mengekspresikan respon dini dari hormon auksin pada tanaman dimana hal tersebut merupakan hal negatif pada tanaman itu sendiri. Deeper Rooting 1 (Dro1), merupakan lokus sifat kuantitatif (QTL) pada tanaman padi yang mengatur sudut pertumbuhan akar (Root Growth Angle). Ekspresi gen DRO1 yang lebih tinggi dapat meningkatkan sudut pertumbuhan akar (Uga et al, 2013). Uga et al. (2011) menyatakan bahwa perakaran dalam merupakan strategi yang berguna untuk melawan kekeringan pada tanaman 
padi. Genotipe yang memiliki perakaran dalam sesuai marka DRO mengindikasikan bahwa aksesi tersebut memiliki produktivitas atau hasil yang tinggi. Ratio Deep Rooting (RDR) atau Rasio perakaran dalam dari QTL Dro1 dipetakan pada jarak $1 \mathrm{cM}$ diantara RM24393 dan RM7424.

Marka RM518 yang terletak pada kromosom 4 dengan posisi $25.5 \mathrm{cM}$. Hasil amplifikasi marka RM518 ini menghasilkan pita monomorfik, sehingga hasilnya tidak bisa digunakan untuk analisis penanda tunggal. Pada penelitian Cheah et al. (2017) menyatakan bahwa marka RM518 digunakan untuk mendeteksi QTL qDTY4.1. qDTY4.1 berlokasi diantara marka RM335 dan marka RM518. QTL tersebut merupakan QTL yang mengatur komponen hasil pada tanaman padi pada stress kekeringan.

\section{KESIMPULAN}

1. Berdasarkan analisis penanda tunggal setiap lokus pada 8 marka yang digunakan memiliki asosiasi dengan 13 karakter agronomi yang berbeda.

2. Setiap lokus yang berasosiasi dengan setiap karakter agronomi tersebut diatur oleh gen mayor.

\section{DAFTAR PUSTAKA}

Bernier J., Kumar A., Ramaiah V., Spaner D., Atlin G.2007. A largeeffect QTL for grain yield under reproductive stage drought stress in upland rice. Crop Sci. 47(2): 507-518.

Boopathi N. M., Swapnashri G., Kavitha P., Sathish S., Nithya R., Ratnam W., Kumar A.2012. Evaluation and bulked segregant analysis of major yield QTL qt/12.1 introgressed into indigenous elite line for low water availability under water stress. Rice Sci. 20(1): 25-30.

BPS. 2015a. Konsumsi Rata-Rata per Kapita Seminggu Beberapa Macam Bahan Makanan Penting, 2007-2014. https://www.bps.go.id/linkTabelStatis/ view/id/950. [15 Desember 2020].

BPS. 2015b. Produksi (ton) padi 2015. https://www.bps.go.id/site/pilihdata.

[15 Desember 2020]

Fujita, D., A.G. Tagle, L.A. Ebron, Y. Fukuta, and N. Kobayashi. 2012. Characterization of near-isogenic lines carrying QTL for high spikelet number with the genetic background of an indica rice variety IR64 (Oryza sativa L.). Breed. Sci. 62: 18-26.

Lin, Meng Hui., C. W. Lin., J. C. Chen., Y. C. Lin., S. Y. Cheng., T. H. Liu., F. J. Jan., S. T. W., F. S. Thseng., H. M. Ku. 2007. Tagging rice drought related QTL with SSR DNA markers. Crop Environment \& Bioinformatics. 1(4): 65-76.

Lin .H. Y., Hour. A.L. 2012. Genetic diversity of rice germplasm used in Taiwan breeding programs. Botanical Studies. 53: 363-376.

Mafaza, Vika Nur., Handoko, Afifudin L. A. 2018. Keragaman genetik karakter morfologi beberapa genotip padi merah (Oryza sativa L.) pada fasse vegetatif dan generatif. Jurnal Produksi Tanaman. 6(2): 3048-3055.

Mishra, K.K., Vikram, P., Yadaw, R.B., Swamy, B.P.M., Dixit, S., Cruz, M.T.S.C., Maturan, P., Marker, S., Kumar, A. 2013. qDTY12.1: a locus with a consistent effect on grain yield under drought in rice. 2013. BMC Genetics. 14: 1471-2156.

Nogoy, F.M., Song JY., Ouk S., Rahimi S., Kwon S.W., Kang KK., Cho Y.G. 2016. Current applicable DNA markers for marker assisted breeding in abiotic and biotic stress tolerance in 
rice (Oryza sativa L.). Plant Breed. Biotech. 4(3): 271-284.

Pandit, Elssa., R.K. Panda., A. Sahoo., D.R. Pani., S.K. Pradhan. 2020. Genetic relationship and structure analysis of root growth angle for improvement of drought avoidance in early and midearly maturing rice genotypes. Rice Science. 27(2): 124-132.

Prasetiyono, Joko., Tasliah., Hajrial A., Sugiono M. 2003. Identifikasi marka mikrosatelit yang terpaut dengan sifat toleransi terhadap keracunan aluminium pada padi persilangan Dupa x ITA131. Jurnal Bioteknologi Pertanian. 8(2): 35-45.

Rahman, M. A.A., M.E. El-denary., M.H. Ammar., A.F., Abdelkhalik., A.E. Draz., S.A. Dora. 2015. QTL validation for grain yield and nitrogen use efficiency under different nitrogen levels in rice. Egypt J. Genet 44: 235251.

Reflinur., Puji. Lestari. 2015. Penentuan lokus gen dalam kromosom tanaman dengan bantuan marka DNA. J. Litbang Pertanian 34 (4): 177-186.

Solis, J., Gutierrez, A., Mangu, V., Sanchez, E., Bedre, R., Linscombe, S., Baisakh, N. 2018. Genetic mapping of QTL for grain yield under drought in rice under controlled green house conditions. Frontiers in chemistry. 5: 129.

Swamy, B.P., Ahmed H.U., Henry, A., Mauleon, R., Dixit, S., Vikram, P., Tilatto, R., Verulkar, S. B., Perraju, P., Mandal, N.P., Variar, M., S. Robin., Chandrababu, R., Singh N.O., Dwivedi, J.L., Das, P.S., Mishra, K.K.,
Yadaw, R.B., Aditya, T.L., Karmakar, B., Satoh, K., Moumeni, A., Kikuchi, S., Leungh, H., Kumar, A. 2013. Genetic, physiological and gene expression analyses reveal that multiple QTL enhance yield of rice megavariety IR64 under drought. Plusone. 8.

Talukdar, Preeti Rekha., S. Ratih., K. Pathak., S K. Chetia. 2017. Population structure and marker-trait association in indigenous aromatic rice. Rice Science. 24(3): 146-154.

Uga ,Y.,Okuno K.,Yano M.2011. Dro1, a major QTL involved in deep rooting of rice under upland field conditions. $J$. Exp Bot. 62: 2485-2494.

Uga, Yusaku., Kazuhiko S., Satoshi O., Jagadish R., Manabu I., Naho H., Yuka K., Yosiai I., Kazuko O., Noriko K., Haruhiko I., Hinako T., Ritsuko M., Yoshiaki N., Jianzhong W., Takashi M., Toshiyuki T., Kazutoshi O., Masahiro Y. 2013. Control of root system architecture by DEEPER ROOTING 1 increases rice yield under drougt conditions. Nature genetic. 45(9): 1097-1101.

Vasant, D.V. 2012. Genome wide association mapping of drought resistance traits in rice (Oryza sativa L.). M Sc. Thesis, Department of Plant Biotechnology, Centre for Plant Molecular Biology and Biotechnology, Tamil Nadu Agricultural University Coimbatore, India.

Yohana, Kesia., Adisyahputra., Kurniawan R. . 2018. Validasi QTL dan aplikasinya untuk perbaikan sifat toleran keracunan Al pada padi (Oryza sativa L.). BIOMA.14(1): 38-48. 